\title{
"УДК 657.42
}

Жураковська I.В., к.е.н., доцент

Луцький національний технічний університет

\section{АНАЛІЗ БУХГАЛТЕРСЬКИХ ПІДХОДІВ У ВИРІШЕННІ ЕКОЛОГІЧНИХ ПРОБЛЕМ}

У статті проаналізовано зміни в бухгалтерському обліку, податках, аудиті, які пов'язанні з вирішенням екологічних проблем світу. Побудовано хронологію змін та перспективи подальшого розвитку обліку. Запропоновано впровадження екологічного балансу для обліку

Ключові слова: екологічний облік, природний капітал, екосистемні послуги.

\section{Zhurakovska I.}

\section{ANALYSIS OF ACCOUNTING APPROACHES IN SOLVING ENVIRONMENTAL PROBLEMS}

The article analyzes changes in accounting, taxes, audits that are related to solving environmental problems in the world. The chronology of changes and prospects for further development of accounting have been constructed. The introduction of an ecological balance for accounting is proposed

Researches rotined that directions of development of ecological account it is enough much and there are changes in relation to introduction of requirements of such account on mokro- and microlevels in a historical prospect. Awareness of importance of account of ecological activity not enough in order that enterprises inculcated him in the registration practice.

We see in an ecological account more more wide setting which consists not only in the reflection of influence on an environment but also him actual consisting and changes of him. Working off opening methods in an account and accounting of enterprise of him ecological activity is the near-term task of accountants of research workers and practical workers.

For implementation of the tasks put before organization of account quite a few is developed and ratified normatively legal certificates, however much all of them touched statistical reports, information for filling of which and until now is not the objects of record-keeping. Instrumental in it and attitude of IFRS toward ecology. After a searching word «Ecology» not a single phrase was found in IFRS and IAS. It is a separate account which can be examined as part statistical or tax.

In fact exactly for the aims of the statistical and tax accounting appear a necessity of account of activity, related both to causing of harm an environment and

\footnotetext{
* Жураковська I.B.
} 
with nature protection measures. To our opinion, from point of method of account, an ecological account must look as balance of «natural capital», where certain factors influence on his diminishing, and other on an increase.

The cost of natural capital includes ekosistemi of favour, that cost of net air, water, rekreaciyni services and others like that An ecological account will be able to execute all tasks fixed on him, if he will be built in obedience to a classic method and double record with the maintainance of balance, in this case by the maintainance of natural capital.

Within the framework of modern record-keeping on mikro- the levels of ekosistemni favour are not represented in none of countries, however much they belong to the national set of accounts in the countries of Europe. To the certain moment national accounts are a lump sum of individual accounts, but only to the certain moment, because limitations exist through the use of different estimations. However one of examples of the use of identical accounts on wetly and microlevels there is the so-called balance of carbon in ecology.

These accounts seem more successive, as an in-use metage - CO 2-equivalent, expressly certain in relation to a global rise in temperature. The task of workersenvironmentalists is an estimation of natural capital taking into account the cost of ekosistemnikh services, and a record-keeping can become basis for adjusting of control after them.

Key words: environmental accounting, natural capital, ecosystem services..

\section{Жураковская И.В.}

\section{АНАЛИЗ БУХГАЛТЕРСКИХ ПОДХОДОВ В РЕШЕНИИ ЭКОЛОГИЧЕСКИХ ПРОБЛЕМ}

В статье проанализированы изменения в бухгалтерском учете, налогах, аудите, которые связаны с решением экологических проблем мира. Построено хронологию изменений и перспективы дальнейшего развития учета. Предложено внедрение экологического баланса для учета.

Ключевые слова: экологический учет, природный капитал, экосистемных услуги.

Постановка проблеми у загальному вигляді та іï зв'язок 3 важливими науковими та практичними завданнями. Вирішення глобальних екологічних проблем $\epsilon$ першочерговим заданням урядів всіх країн. Збереження довкілля пов'язано з поняттям природного капіталу, який поряд 3 економічним і соціальним управляється суспільством. Його поява пояснюється намаганням зберегти довкілля, щоб майбутні покоління мали можливість користуватись дарами природи. 
Для реалізації концепції природного капіталу екологи об'єднуються з бухгалтерами, щоб виміряти і відобразити його вартість. Суцільний облік витрат на екологію, оцінка шкоди та інші пропозиції щодо реформи бухгалтерського обліку не можуть бути вирішеними в межах однієї окремої країни. Адже такі ресурси як вода і повітря, які потребують відновлення, мають бути оцінені скрізь. Аналіз сучасних бухгалтерських підходів щодо вирішення екологічних проблем вказує на міжнародний підхід в реалізації завдань екологічного обліку. В мажах локальних облікових систем можна забезпечити відновлення природного капіталу хоча б державного значення, що потребує адаптації існуючих методів обліку і контролю капіталу до екологічної діяльності.

Аналіз останніх досліджень, у яких започатковано вирішення проблеми. Серед вчених, які вивчали екологічний облік, податки та «природний капітал» слід виділити Канонічна-Коваленко К., Замула I.В, Мельник Л.Г., Шевчук В.О., Жан Луї Вебер, д’Арге, Р. де Гроот Р., Фарбер С., Грассо, М., Хеннон, Б. Ван ден Бельт М. Проте кожен $з$ них окремо розглядав вузьку сферу вдосконалення екологічного обліку, податків, оцінки екосистемних послуг і т.д.

Цілі статті. Метою дослідження є виявлення ролі, бухгалтерського, статистичного обліку, податків та аудиту у вирішенні екологічних проблем та розробка перспектив вдосконалення бухгалтерського обліку для забезпечення інформаційної основи прийняття екологічних рішень.

Виклад основного матеріалу дослідження 3 повним обгрунтуванням отриманих наукових результатів. Цілий ряд останніх міжнародних ініціатив вплинули на вітчизняну систему екологічної звітності, починаючи 3 Директиви 2001/42/СС Європейського парламенту та ради від 27 червня 2001 року «Про оцінку наслідків окремих планів та програм для довкілля» [1], Міжнародного статистичного стандарту «Система екологоекономічного обліку Центральної рамки»[2] (SEEA CF), «Експериментальний облік екосистем»[3] (SEEA-EEA) Статистичної комісії ООН. 
Нами досліджено, що екологічні питання увійшли через нормативне регулювання до сфер аудиту фінансової звітності, статистики, податків в Україні через впровадження міжнародних стандартів та вітчизняне законодавство (рис.1)

\section{Бухгалтерський облік}

•Екологічний облік лише на теоретичному рівні

\section{Фінансова звітність}

-Методичні рекомендації зі складання звіту про управління, затверджено наказом Міністерства фінансів України від 07.12.2018 ㄴ 982

\section{Статистика}

- Міжнародні статистичні стандарти SEEA, «Стратегічна екологічна оцінка» (СЕО) «Директива 2001/42/ЕС про оцінку впливу окремих планів та програм на навколишнє середовище»

\section{Податки}

•Розділ VIII, XIПодаткового кодексу України, екологічний податок, рентні платежі

\section{Аудит фінансоврї звітності}

- Міжнародний стандарт аудиту з надання впевненоті 3410 «Завдання 3 надання впевненості щодо звітів з парникових газів»

Рис. 1. Екологічні питання в нормативному регулюванні обліку, статистики, податків та аудиту фінансової звітності

Для імплементації вимог Директиви 2013/34/ЄС Європейського парламенту та ради Європейського союзу від 26 червня 2013 року про щорічну фінансову звітність, консолідовану фінансову звітність та пов'язані з ними звіти певних типів компаній [4], були внесені зміни до Закону України «Про бухгалтерський облік та фінансову звітність» від 16 липня 1999 року № 996-XIV щодо необхідності подання звіту про управління. Методичні рекомендації зі складання звіту про управління, затверджено наказом Міністерства фінансів України від 07.12.2018 № 982 встановлюють структу- 
"Економічні науки". - Серія "Облік і фінанси". - Випуск 16 (61). - 2019.

ру інформації про екологічну діяльність як складової звіту про управління.

Україною впроваджено в практику Міжнародні статистичні стандарти SEEA Статистичної комісії ОOH. Підприємства щороку подають звітність щодо довкілля (табл.1)

Таблиця 1

Статистична звітність 3 навколишнього середовища

\begin{tabular}{|c|c|c|c|}
\hline $\begin{array}{l}\text { № } \\
\text { 3/ח }\end{array}$ & Назва звіту & Код звіту & Облікове забезпечення \\
\hline 1. & $\begin{array}{c}\text { Звіт про викиди забру- } \\
\text { днюючих речовин і } \\
\text { парникових газів у } \\
\text { атмосферне повітря від } \\
\text { стаціонарних джерел } \\
\text { викидів (06.07.2018 } \\
\text { №124) }\end{array}$ & $\begin{array}{l}2-\mathrm{TП} \\
\text { (повітря) } \\
\text { (річна) }\end{array}$ & $\begin{array}{c}\text { Забруднюючі речовини не є } \\
\text { об’єктами бухгалтерського } \\
\text { обліку. При заповненні викори- } \\
\text { стовується технічна документа- } \\
\text { ція, розрахунки інженерів. Ці ж } \\
\text { дані беруться за основу для } \\
\text { обчислення об'єкта оподатку- } \\
\text { вання екологічним податком }\end{array}$ \\
\hline 2. & $\begin{array}{c}\text { Витрати на охорону } \\
\text { навколишнього приро- } \\
\text { дного середовища та } \\
\text { екологічні платежі за } \\
20 \text { рік (30.09.2015 } \\
\text { №259 (зі змінами)) }\end{array}$ & $\begin{array}{l}1- \\
\text { екологічні } \\
\text { витрати } \\
\text { (річна) }\end{array}$ & $\begin{array}{c}\text { Витрати на охорону навколиш- } \\
\text { нього середовища є об'єктом } \\
\text { обліку, відображаються на } \\
\text { аналітичних рахунках }\end{array}$ \\
\hline 3. & $\begin{array}{c}\text { Утворення та пово- } \\
\text { дження з відходами за } \\
20 \_ \text {рік (19.08.2014 } \\
\text { №243 (зі змінами)) }\end{array}$ & $\begin{array}{c}\text { 1-відходи } \\
\text { (річна) }\end{array}$ & $\begin{array}{c}\text { Більшість відходів не є } \\
\text { об’єктами обліку. Їх кількість } \\
\text { для звіту обчислюється з техні- } \\
\text { чної документації, факт може } \\
\text { значно відрізнятись }\end{array}$ \\
\hline
\end{tabular}

Об’єктами статистичного спостереження є відновлювальні і невідновлювальні природні ресурси. Відображаються в статистичній звітності, але не є об'єктом бухгалтерського обліку стан і повнота використання корисних копалин, земельних, лісових, водних, рибних ресурсів і тваринного світу, стан охорони повітряного басейну.

Облік витрат на охорону навколишнього середовища $є$ частиною розширеної структури національних рахунків. Класифікація природоохоронних заходів та витрат на найвищому рівні розрізняє наступні сфери: захист навколишнього повітря та клімату; управління стічними водами; поводження з відходами; охорона та відновлення грунтів, грунтових та поверхневих вод; зменшення 
шуму та вібрації (крім захисту робочого місця); захист біорізноманіття та ландшафтів; захист від радіації (виключаючи зовнішню безпеку); дослідження та розвиток; та інші заходи з охорони навколишнього середовища (включаючи державні витрати) [2; 3].

До прийняття Податкового кодексу України у 2011 році екологічні податки в Україні називалися зборами за забруднення навколишнього природного середовища. У 2006-2012 рр. частка платежів за ресурси становила менше 5 \%, а частка екологічного податку не перевищувала $1 \%$. У розвинутих країнах світу введення екологічного податку зумовлене потребою часткової компенсації негативного впливу на довкілля небезпечних факторів, що виникають у процесі діяльності суб'єктів господарювання [7]. Проте в Україні цей механізм не працює. Наприклад, всіма підприємствами України у 2018 році було сплачено екологічного податку 48,5 млрд. грн.[8], а інвестиції на охорону навколишнього середовища за даними Державного комітету статистики склали тільки 10,07 млрд.грн, тобто $18 \%$ сплаченої суми. Тому екологічне оподаткування також потребує суттєвих змін щодо розподілу податкових надходження, введення податкових пільг при наявності капіталовкладень на екологічні заходи і т.д.

Зважаючи на обов'язкову наявність в звітності деяких підприємств показників екологічної діяльності, з 2013 року впроваджено Міжнародний стандарт аудиту для надання впевненості 3410 «Завдання $з$ надання впевненості щодо звітів 3 парникових газів».

Інформаційною основою для складання згаданих вище звітів $\epsilon$ дані, які жодним чином не реєструються в бухгалтерському обліку. Для вирішення цього та ряду інших завдань сучасного обліку в науковій спільноті обговорюється вдосконалення екологічного обліку. Законом України «Про Основні засади (стратегію) державної екологічної політики України на період до 2030 року», від 28 лютого 2019 року № 2697-VIII вперше в законодавстві України подане визначення екологічного обліку. Екологічний облік - забезпечить виявлення, реєстрацію, узагальнення, зберігання, оброблення та підготовку релевантної інформації про діяльність підприємства в природоохоронній сфері з метою передачі іiі внутрішнім і зовнішнім користувачам та сприятиме прийняттю управлінських рішень $з$ урахуванням економічної ефективності, соціальної справедливості та екологічної цілісності. Екологічний облік - це спроба 
розширити сферу рамок бухгалтерського обліку, що використовуються для оцінки економічних показників, які не фіксуються в діяльності приватних чи державних установ [9].

На підставі досліджень праць $[9 ; 10 ; 11 ; 12]$, нами визначено початки формування екологічного обліку у XVIII столітті. Однак рушійні кроки, які підняли всю світову спільноту щодо вирішення екологічних проблем, почались з 1992 року, коли на конференції ООН було прийнято рішення про звернення до всіх країн. (рис.2):

До основних завдань екологічного обліку слід віднести

\section{Завдання екологічного обліку}

Зібранняданих, закладених у існуючій системі обліку, длянадання більш детальної інформації розробникам екологічних програм та рішень

Розширення меж облікудля забезпечення інформацією екологічної політики

Обчислення витрат пов'язаних з деградацію навколишнього середовища 3 метою виправлення показникаВВП, ВНП

Розширення меж обліку для оцінки запасів віддалених або незайманих природних ареалів

Інтеграція економічного капіталу з природним капіталом

Вимірювання екологічної цінності екосистем та створення екологічних балансів для всіх секторів економіки

Оцінка вартості активів неринкових послуг екосистеми в оцінках загального багатства

Рис. 2. Завдання екологічного обліку

Усвідомлення важливості обліку екологічної діяльності недостатньо для того, щоб підприємства впровадили його у свою облікову практику. В такій ситуації необхідне нормативне закріплення. Відсутність національних стандартів обліку екологічної 
діяльності спонукало Міжурядову робочу групу в 1991 р. розробити перші рекомендації для бухгалтерів, де вказувалося, що повинно бути представлено у фінансових звітах, щоб користувачі могли оцінити реальну картину впливу господарської діяльності підприємства на природне середовище.

Стаття 24 Закону України «Про охорону навколишнього природного середовища» від 25 червня 1991 року № 1264-XII передбачає, що «підприємства, установи та організації проводять первинний облік у галузі охорони навколишнього природного середовища і безоплатно подають відповідну інформацію органам, що ведуть облік у цій галузі. В своїх дослідженнях І.В. Замула зазначає, що раціональне екологічне управління підприємством передбачає ведення максимально пристосованого до його вимог бухгалтерського обліку, на підставі даних якого і буде формуватися реальна картина впливу підприємства на довкілля [10].

Проте, ми вбачаємо більш ширше призначення екологічного обліку, яке полягає не тільки у відображенні впливу на середовище, а й його фактичного стану і змін в ньому. Відпрацювання способів розкриття в обліку та звітності підприємства його екологічної діяльності є першочерговим завданням бухгалтерів науковців та практиків. Для виконання поставлених перед організацією обліку завдань розроблено і затверджено цілу низку нормативно-правових актів, однак всі вони стосувались статистичних звітів, дані для заповнення яких і досі не є об'єктами бухгалтерського обліку. Цьому сприяє і відношення МСФЗ до екології. За пошуковим словом «Екологія» в МСФЗ та МСБО не було знайдено жодної фрази. Тільки в Тлумаченнях КТМФЗ є окремі роз'яснення щодо відповідальності підприємств за нанесену природі шкоду (табл. 2).

Таблиця 2

Згадки МСФЗ та МСБО про екологію

\begin{tabular}{|c|c|c|}
\hline $\begin{array}{c}\text { № } \\
\text { з/п }\end{array}$ & Тлумачення & $\begin{array}{c}\text { Суть розкриття у фінансовій звітності інфо- } \\
\text { рмації про шкоду екології }\end{array}$ \\
\hline 1 & 2 & 3 \\
\hline 1 & $\begin{array}{c}\text { ТЛУМАЧЕННЯ } \\
\text { КТМФ3 1 «Змі- } \\
\text { ни в існуючих }\end{array}$ & $\begin{array}{c}\text { Це Тлумачення застосовується до змін в } \\
\text { оціні зобов'язань 3 виведення з експлуата- } \\
\text { ції, відновлення та подібних зобов'язань. }\end{array}$ \\
\hline
\end{tabular}


"Економічні науки". - Серія "Облік і фінанси". - Випуск 16 (61). - 2019.

Продовження табл. 2

\begin{tabular}{|c|c|c|}
\hline 1 & 2 & 3 \\
\hline & $\begin{array}{l}\text { зобов'язаннях } 3 \\
\text { виведення } 3 \\
\text { експлуатації, } \\
\text { відновлення та } \\
\text { подібних зо- } \\
\text { бов'язаннях» } \\
\end{array}$ & $\begin{array}{c}\text { Наприклад, зобов’язання з виведення з екс- } \\
\text { плуатації, відновлення та подібні зо- } \\
\text { бов'язання можуть існувати стосовно виве- } \\
\text { дення із експлуатації виробничих потужнос- } \\
\text { тей, виправлення екологічної шкоди видобу- } \\
\text { вних галузей або переміщення обладнання. }\end{array}$ \\
\hline 2 & $\begin{array}{l}\text { ТЛУМАЧЕННЯ } \\
\text { КТМФЗ } 5 \text { «Пра- } \\
\text { ва на частки у } \\
\text { фондах на виве- } \\
\text { дення з експлуа- } \\
\text { тації, відновлен- } \\
\text { ня та екологічну } \\
\text { реабілітацію» }\end{array}$ & $\begin{array}{c}\text { Призначенням фондів на виведення з екс- } \\
\text { плуатації, відновлення та екологічну реабілі- } \\
\text { тацію є відокремлення активів для фінансу- } \\
\text { вання деяких або всіх витрат на виведення з } \\
\text { експлуатації основних виробничих засобів } \\
\text { (таких як атомна станція) чи певної техніки } \\
\text { (такої як автомобілі) або на виконання зо- } \\
\text { бов’язань з екологічної реабілітації (таких як } \\
\text { усунення забруднення води чи відновлення } \\
\text { землі після відкритої розробки корисних } \\
\text { копалин), в подальшому об'єднаних термі- } \\
\text { ном «виведення з експлуатації». }\end{array}$ \\
\hline 3 & $\begin{array}{l}\text { ТЛУМАЧЕННЯ } \\
\text { КТМФЗ } 6 \text { «Зо- } \\
\text { бов’язання, що } \\
\text { виникають вна- } \\
\text { слідок участі у } \\
\text { специфічному } \\
\text { ринку - відходів } \\
\text { електричного та } \\
\text { електронного } \\
\text { обладнання }\end{array}$ & $\begin{array}{c}\text { Директива Свропейського Союзу «Відходи } \\
\text { електричного та електронного обладнання» } \\
\text { (ВЕЕО), яка регулює збирання, обробку, } \\
\text { утилізацію та екологічно безпечну ліквіда- } \\
\text { цію відходів обладнання, викликала питання } \\
\text { стосовно того, коли слід визнавати зо- } \\
\text { бов’язання щодо виведення із експлуатації } \\
\text { ВЕЕО. Директива розрізняє «нові» та «істо- } \\
\text { ричні» відходи, а також відходи приватних } \\
\text { домогосподарств і відходи з інших джерел, } \\
\text { що не є приватними домогосподарствами. } \\
\text { Нові відходи пов’язані з продукцією, прода- } \\
\text { ною після } 13 \text { серпня } 2005 \text { р. Все обладнання } \\
\text { побутового призначення, продане раніше } \\
\text { цієї дати, вважається таким, що створює } \\
\text { історичні відходи для цілей цієї Директиви. }\end{array}$ \\
\hline
\end{tabular}

Таким чином екологічний облік в Україні на законодавчому рівні $є$ новим поняттям. Він передбачає накопичення і узагальнення інформації про екологічну діяльність, яка не знаходить поки свого 
повного відображення в бухгалтерському обліку, але розкривається у фінансовій звітності. Підтвердженням цього є відсутність відповідних вимог в МСФЗ та МСБО. Це окремий облік, який можна розглядати як частину статистичного чи податкового. Адже саме для цілей статистичної та податкової звітності виникає необхідність обліку діяльності, пов'язаної як з нанесенням шкоди довкіллю, так і з природоохоронною діяльністю.

Облік не забезпечений належними вимогами, що потребує суттєвого доопрацювання. На нашу думку, екологічний облік підприємств має відображати наступні об'єкти в натуральних і вартісних вимірниках, які розроблені в рамках Директиви 2001/42/ЕC «Про оцінку впливу окремих планів та програм на навколишнє середовище»:

- захист навколишнього повітря та клімату;

- управління стічними водами;

- поводження з відходами;

- охорона та відновлення грунтів, грунтових та поверхневих вод;

- захист біорізноманіття та ландшафтів;

- інші заходи з охорони навколишнього середовища (включаючи державні витрати);

- екосистемні послуги (тільки для деяких підприємств i установ, наприклад для лісогосподарських підприємств - чисте повітря, збереження ландшафту, рекреація і т.д).

Для кожного звітного періоду не достатньо лише констатувати перелік витрат на охорону довкілля, чи приріст насаджень, необхідно визначати сукупний вплив на природний капітал, щоб контролювати його зменшення. 3 точки зору методики обліку, це виглядає як баланс «природного капіталу», де певні фактори впливають на його зменшення, а інші на збільшення, що представлено на рис.3. Сама ж вартість природного капіталу включає екосистемні послуги, тобто вартість чистого повітря, води, рекреаційні послуги i і.т.п. Приклад оцінки екосистемних послуг в Україні можна знайти щодо Голосіївського парку [14]. 


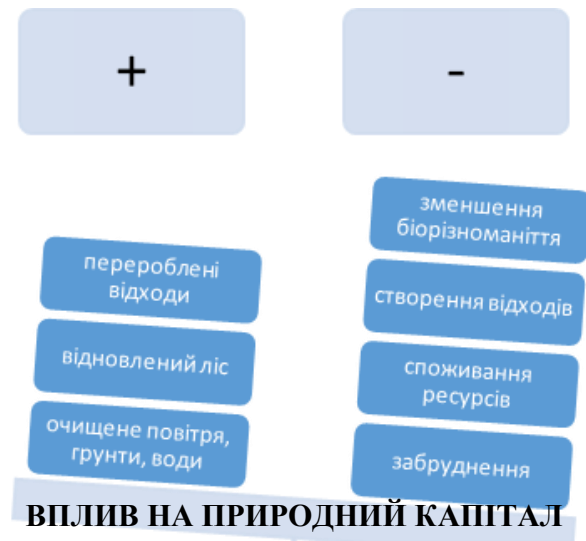

Рис.3. Схематичне зображення об’єктів екологічного обліку

Висновки. Екологічний облік зможе виконувати всі покладені на нього завдання, якщо він буде побудований згідно класичної методики і подвійного запису із збереженням балансу, в даному випадку збереженням природного капіталу. Вартість природного капіталу формується в основному за рахунок екосистемних послуг.

У рамках сучасного бухгалтерського обліку на мікро- рівні екосистемні послуги не відображаються в жодній $з$ країн, проте вони належать до національної системи рахунків в країнах Європи. До певного моменту національні рахунки - це загальна сума індивідуальних рахунків, але лише до певного моменту, тому що обмеження існують через використання різних оцінок. Проте одним із прикладів використання однакових рахунків на макро і мікрорівнях в екології є так званий баланс вуглецю [9]. Ці рахунки здаються більш послідовними, оскільки використовувана одиниця вимірювання - $\mathrm{CO}_{2}$-еквівалентний, чітко визначений стосовно глобального потепління. Завданням науковців-екологів є оцінка природного капіталу з врахуванням вартості екосистемних послуг, а бухгалтерський облік може стати основою для налагодження контролю за ними.

Впровадження цієї концепції в облік вимагає уточнення всіх базових понять, адже корисність таких активів вимірюється не тільки в економічних вигодах. Майже всі активи природного капі- 
талу вже сьогодні підлягають бухгалтерському обліку, бухгалтерському балансу: земля, біологічні активи, екологічні витрати, природні ресурси і т.д. Але облікова система не передбачає одночасного оцінювання шкоди для забезпечення їх відтворення не нижче певного критичного рівня. В чому і суть капіталу - поряд з активами забезпечити джерела їх відтворення.

1. Economy-wide material flow accounts (EW-MFA): Compilation Guide 2013. Eurostat, Luxembourg. URL: https://ec.europa.eu/eurostat/documents/ 1798247/6191533/2013-EW-MFA-Guide-10Sep2013.pdf/54087dfb-1fb0-40f2b1e4-64ed22ae3f4c (дата звернення: 3.11.2019).

2. System of environmental-economic accounting 2012: Central framework. New York: United Nations. URL: https://unstats.un.org/unsd/envaccounting/ seearev/seea_cf_final_en.pdf (дата звернення: 3.11.2019).

3. System of environmental-economic accounting 2012: Experimental ecosystem accounting. New York: United Nations. URL: https://ec.europa.eu/eurostat /documents/3859598/6925551/KS-05-14-103-EN-N.pdf (дата звернення: 3.11.2019).

4. The changing wealth of nations: Measuring sustainable development in the new millennium. Washington, DC: The World Bank. URL: http://documents.worldbank.org/curated/en/630181468339656734/The-changingwealth-of-nations-measuring-sustainable-development-in-the-new-millennium (дата звернення: 3.11.2019).

5. ДИРЕКТИВА 2001/42/ЄС ЄВРОПЕЙСЬКОГО ПАРЛАМЕНТУ ТА РАДИ від 27 червня 2001 року про оцінку наслідків окремих планів та програм для довкілля. URL: https://minjust.gov.ua/m/str_45875 (дата звернення: 3.11.2019).

6. ДИРЕКТИВА 2013/34/ЄС ЄВРОПЕЙСЬКОГО ПАРЛАМЕНТУ ТА РАДИ ЄВРОПЕЙСЬКОГО СОЮЗУ від 26 червня 2013 року про щорічну фінансову звітність, консолідовану фінансову звітність та пов'язані з ними звіти певних типів компаній, що вносить зміни до Директиви 2006/43/СС Європейського Парламенту та Ради та скасовує Директиву Ради 78/660/СЕC і 83/349/СЕС. URL: https://minjust.gov.ua/m/str_45875 (дата звернення: 3.11.2019).

7. Екологічний податок-2019 в Україні: «гарячі» зміни як крок до європейської моделі розвитку чи елемент посилення тиску на бізнес? URL:.http://ecologua.com/articles/ekologichnyy-podatok-2019-v-ukrayini-garyachi-zminy-yak-krokdo-yevropeyskoyi-modeli (дата звернення: 3.11.2019).

8. Канонішена-Коваленко К. Екологічний податок від А до Я. Київ: Фундація «Відкрите Суспільство», 2017. 108 с.

9. Jean Louis Weber. Environmental Accounting. URL: https://oxfordre.com/environmentalscience/view/10.1093/acrefore/9780199389414. 001.0001/acrefore-9780199389414-e-105 (дата звернення: 3.11.2019).

10. Замула І.В Екологізація управління підприємством: роль бухгалтерського обліку. Міжнародний збірник наукових праць ЖДТУ. 2006. Випуск 3(6). С.7786. URL: http://library.ztu.edu.ua/e-copies/Zbirnyk/Problems_\%20accounting 
_3_6/77.pdf (дата звернення: 3.11.2019).

11. Costanza, R., d'Arge, R., de Groot, R., Farber, S., Grasso, M., Hannon, B. van den Belt, M.. The value of the world's ecosystem services and natural capital. Nature, 387,1997. P.253-260.

12. Costanza, R., Cumberland, J. H., Daly, H., Goodland, R., Norgaard, R. B., Kubiszewski, I., et al. . An introduction to ecological economics. Boca Raton, FL: CRC Press.:2014. URL: http://library.uniteddiversity.coop/Measuring _Progress_and_Eco_Footprinting/An_Introduction_to_Ecological_Economics.pdf (дата звернення: 3.11.2019).

13. Peskin, H. M. A national accounting framework for environmental assets. Journal of Environmental Economics and Management, 1976. №2, p. 255-262.

14. Екосистемні послуги Голосіївського лісу. URL: http://uacrisis.org/ua/66526golosiyivskyj-park (дата звернення: 3.11.2019).

15. Helm Dieter. Natural capital: assets, systems, and policies. OXFORD REVIEW OF ECONOMIC POLICY. 2019. T: 35. № 1. P. 1-13.

"УДК 332.12(477)

Забедюк М.С., к.е.н., доцент

Луцький національний технічний університет

\section{ТЕОРЕТИЧНІ АСПЕКТИ УПРАВЛІННЯ ОБОРОТНИМ КАПІТАЛОМ ПІДПРИЕМСТВА}

У статті висвітлено сутність та основні завдання управління оборотним капіталом підприємства. Розглянуто принципи та функції управління оборотним капіталом підприємства. Виокремлено чинники, які спричиняють негативний вплив на формування та використання оборотного капіталу підприємства.

Ключові слова: оборотний капітал, управління оборотним капіталом, структура капіталу, підприємство.

\section{Zabedyuk M. \\ THEORETICAL ASPECTS OF CURRENT ASSETS MANAGEMENT OF THE ENTERPRISE}

The article covers the essence and main tasks of managing current assets of the enterprise. In today's business environment, the activity of enterprises is closely linked to the formation and use of current assets, which has a special place in the capital structure of the enterprise. At the same time, the continuity of the production and sale of products, liquidity of the enterprise, its solvency and profitability depend on the quality

\footnotetext{
* Забедюк М.C.
} 